\title{
Clicker Supported Team-Based Learning Environment: A Qualitative Study
}

\author{
https://doi.org/10.3991/ijoe.v14i09.8734 \\ Gülsüm Aşıksoy \\ Near East University, Nicosia, North Cyprus, Turkey \\ gulsum.asiksoy@neu.edu.tr
}

\begin{abstract}
In recent years, Clicker technology has been widely used at universities to provide interactive learning environments. It is used with appropriate pedagogic approaches to achieve expected learning outcomes. This study aims to determine the views of students about learning environment developed based on the integration of Team-based learning strategy and clicker technology in education. The participants included 30 first-year engineering students taking Physics-I at Near East University. Data were collected with a semi-structured interview form developed by the researcher after a comprehensive analysis of the literature. Interviews were carried out at the voluntary base after a five-week application process. The data were analyzed through content analysis method. Results of the study showed that perceptions of students who received education in clicker supported Team-Based learning environment were positive. Students stated that this environment enhanced their learning and they also provided recommendations. It is expected that this study would contribute educators in terms of integrating clicker technology in team-based learning strategy.
\end{abstract}

Keywords-Clickers, learning, team based learning, physics education.

\section{Introduction}

Use of Information Technology in education has positive outcomes and this is a theoretical reality accepted by the majority of educators [1]. Technology is the only tool which helps learners to reach learning materials easily and it is also a unique tool that eliminates the obstacles in terms of time and place [2]. When integration of technology in education is considered, use of developed and new devices is not sufficient in order to achieve the expected performance [3]. Integration of technology into teaching-learning environments through an applicable teaching design enhances communication between students, increases their motivation and promotes meaningful and permanent learning [4].

Clickers are considered as one of the most promising tools to activate learning environments in the future and products of teaching technologies in classroom environment [5], [6]. Clickers are used in classroom to increase interest in the subject, make the learning environment entertaining, raise motivation and get instant feedback [7], [8]. Clickers, also named as Audience Response System (ARS), Personal Response 
System (PRS) or Classroom Response System (CRS), are composed of three basic components. These components are priority, a computer or a smart phone in which the teacher asks questions, directs the activities, the students see the answers or in which the teacher has the control through searching the internet; portable devices in which students see the questions and make choices and a screen in which the answers are instantly displayed. Responses of the students, if preferred, can be shared, recorded and saved on the database of the system or on the main computer the teacher uses. The system makes it possible to make rapid changes during the lecture [5].

According to literature, several studies have shown the advantages of clickers in teaching environments. Some of these advantages are making students actively participate in the lesson [9], having more interaction between the teacher and student, raising motivation, supporting teacher-student relationship and revealing misunderstanding through instant feedback [10], [7]. There are several studies which examined the use of clickers in classroom environment. For example, in a study by [11] on the use of clickers in Nursing education, it was found that these systems promoted learning, raised active participation of students and raised motivation. Blasco-Arcas [12] formed a theoretical framework to raise students' learning performance and stated that clickers support students' group-work. In another study by [13], the effect of clicker technology on student participation and exam performances in a bio-chemistry lesson was investigated. It was revealed that students learned concepts more easily and correctly through clicker technology at the end of the study. [14] stated that clickers raised concentration and prevented incorrect learning. Similarly, [15] showed that clicker use in classroom environment increased student achievement. In the study, it was also found that female students' achievement rates were higher compared to male students. One other study [16] examined student perceptions on the use of clickers in classrooms and revealed that female students' perceptions were more positive compared to male students.

There are many researches in the literature which investigated the students' individual preference to use clicker technology in classroom environment [17], [18]. On the other hand, a few studies showed that team work in learning and using clickers yielded better results [19]. In this respect, different findings from researches in the relevant literature and the limited number of studies on using clicker in groups were the foundations of the present study.

Therefore, team based learning strategy and appropriate integration of clickers was carried out and student views about this new created environment were examined through the following questions;

1. What are students' views about clicker supported team based learning environment?

2. What are the students' recommendations towards enhancing the clicker supported team-based learning environment? 


\section{Methodology}

Qualitative research method was used in the study. The semi-structured interview which is one of the qualitative research techniques has been employed in order to determine the students' views towards the clicker supported team-based learning environment and to identify their recommendations for enhancing the environment.

\subsection{Participants}

Thirty first year students, in which the majority of them $(n=28)$ had never used clickers in class before, taking Physics I course at the Faculty of Engineering, Near East University, in Fall 2017-2018 academic year participated in this study. Students' demographic characteristics are shown in Table 1.

Table 1. Students' Demographic Characteristics

\begin{tabular}{|l|c|}
\hline \multicolumn{1}{|c|}{ Demographic Characteristics } & Frequency (n) \\
\hline Gender & 30 \\
\hline Male & - \\
\hline Female & 2 \\
\hline Previous experience in the use of clicker in class & 28 \\
\hline Yes & \\
\hline No & \\
\hline
\end{tabular}

\section{2 $\quad$ Course Settings}

This research was carried out within the context of Physics-I at the Faculty of Engineering, Near East University. During the study for five weeks, the classes were performed by the researcher who is an expert in Physics. The students had Physics I classes twice a week for 90 minutes. The first 45 minutes of the classes were allocated for the presentation of the subject with the guidance of the lecturer and questions of the students. The second 45 minutes were spent on problem solving by using clicker, discussion and question-answer activities. For these activities, Socrative software application was used. The first reason for using this application was the researcher's qualification in the use of Socrative. The second reason was because being free and the third reason was, contrary to some other clicker applications, this application could be used both on Android and IOS platforms as well as on any internet browser. The students downloaded "Socrative Student" application either from www.socrative.com through "Student Login", Android based phones or tablet computers. Problem sets with maximum five questions in problem solving activities were prepared by the subject teacher. More than one problem sets were prepared according to the content of the lesson. 


\subsection{Clicker Supported Team-Based Learning Environment}

The students created six groups of five with their friends (T1, T2, T3, T4, T5, T6). The seating arrangement was formed in such a way that students in the same groups sat side-by-side and this remained as the same for five weeks.

In the first 45 minutes, the lecture was introduced, students asked for clarification of unclear subjects and reached a solution by discussing among themselves. In cases where they could not find an answer to a question, the lecturer guided them to find the solution, but did not answer the question. During the second 45-minute period, activities in problem solving were carried out through Socrative's Space Race property. Every team had its name and different colored spaceships. As the teams answered questions correctly, the spaceships moved forward. The fastest group who reached the finish point won the competition. Meanwhile, the lecturer's screen was projected so that students could watch their progress (Figure 1).

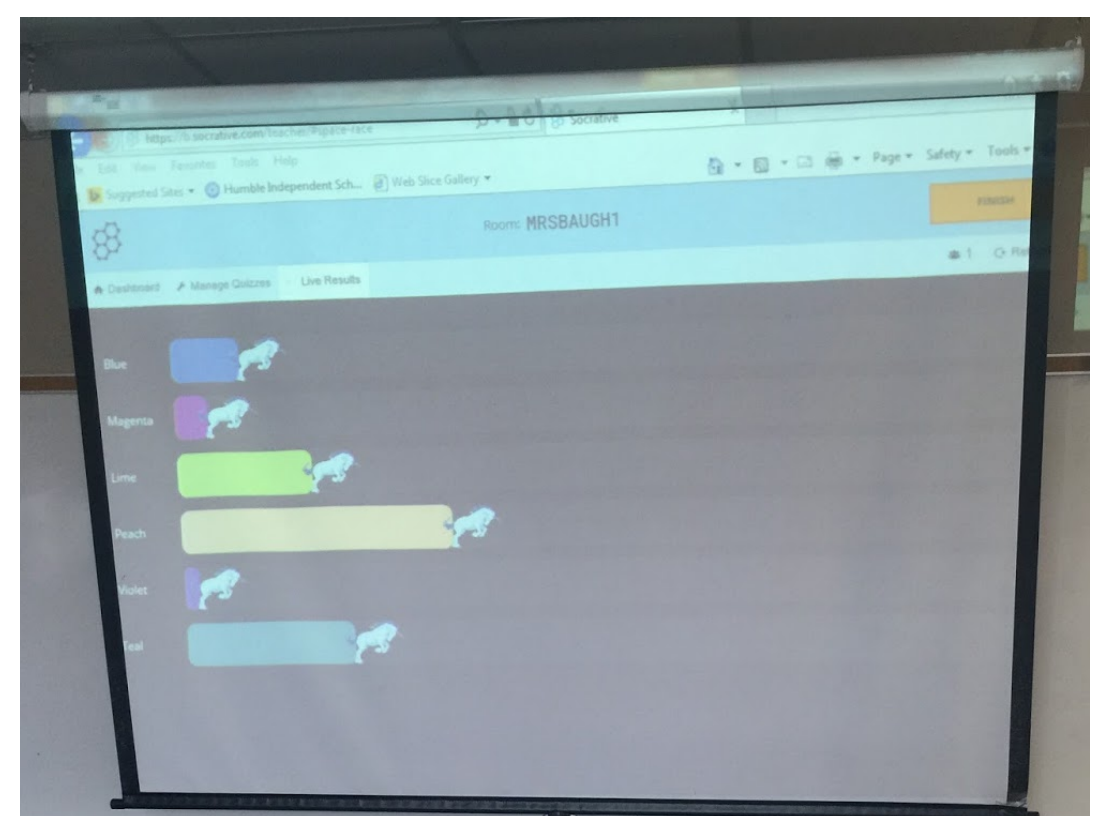

Fig. 1. Space Race screen view

One student from each group logged in Socrative. The first problem set with maximum five questions was asked to students through Socrative Space Race application. The students discussed all questions in the team and as they solved the problems, they sent the answers through Socrative Space Race. After giving feedback to the teams, extra time was allocated to discuss their answers (correct/wrong). This activity lasted till the end of the lecture. The course structure is shown in Figure 2. 


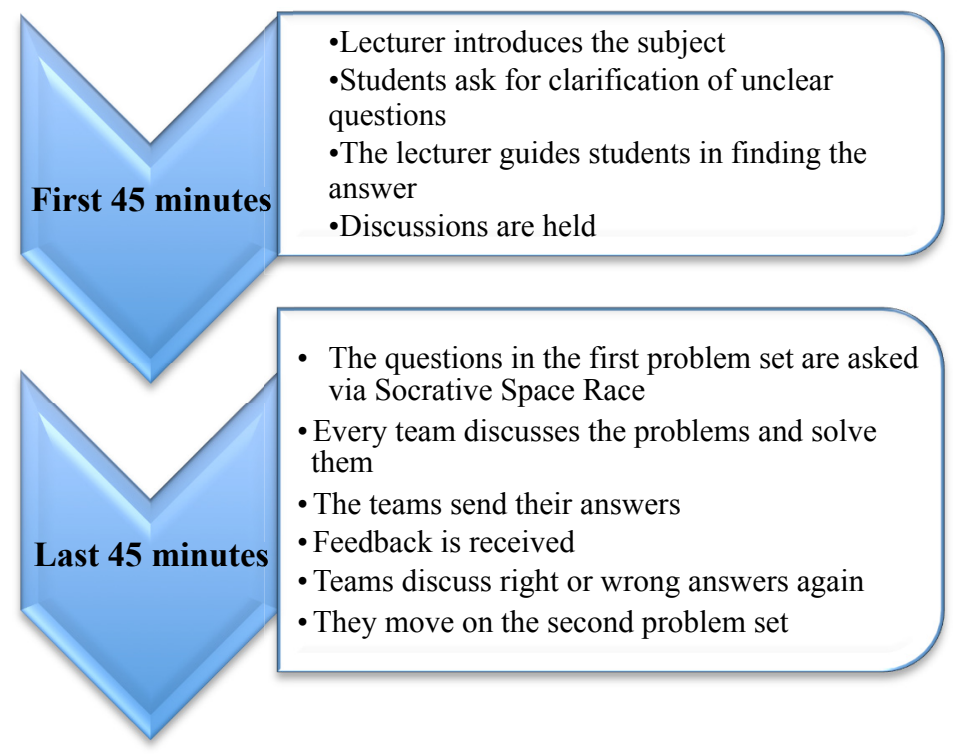

Fig. 2. The course structure

\section{$2.4 \quad$ Instruments}

A semi-structured interview form was prepared to determine students' views about the environment in which Physics lessons were held. Relevant literature review was carried out when writing questions to ensure content validity [20]. In order to confirm the clarity and suitability of the questions, views of two experts from educational technology and one expert in Physics were received. Necessary corrections were made and the questions were finalized based on their feedback. The interviews with 21 students were held on voluntary bases. In order to prevent data loss, the interviews were recorded with the participants' consent and edited afterwards. Every interview lasted for about 6 minutes.

\subsection{Data analysis}

Five weeks after the application, semi-structured interviews were held with 21 volunteering students in order to determine their views on clicker supported team-based learning environment. Individual interviews were carried out with each student and permission was obtained from the students for voice recording before the interview. The students have been informed that their names would be anonymous for them to express their ideas without any pressure. As an ethical approach, students' names were represented as S1, S2, S3 etc. Each interview that was recorded has been transcribed into Microsoft Word program. The themes and sub-themes were formed by applying the content analysis method to the qualitative data that have been obtained. The process of constituting the theme and sub-themes was organized by bringing the 
similar expressions together with the prominent concepts (codings) and themes. The suitability of the coding was confirmed by two peer reviewers. 16 of 18 codes formed by the researchers were approved by the reviewers. The agreement percentage formula suggested by [21] (Agreement Percentage=Agreement/Agreement+Disagreement) $\mathrm{x} 100$ ) was $88 \%$ between the researcher and the experts. A value over $80 \%$ is accepted as reliable for any research [21]. The codes disagreed on were accepted in the light of the researcher's suggestions and were finalized. The frequencies of the codes and themes were calculated and shown with tables. For the validity and reliability of the results, the findings were explained in detail based on quotations [22]. As an ethical approach, students' names were represented as S1, S2, S3 etc.

\section{Results}

\subsection{Students' views about clicker supported team-based learning environment}

In order to determine the students' views regarding the environment developed for the study, they were asked the following question; "What do you think about having Physics lessons in Clicker Supported Team-based Learning Environment? Explain". The qualitative data collected from the students' answers were put into two themes as "Positive" and "negative". Two different sub-themes as "learning" and "engagement" were obtained under the "positive" theme. One student stated views on one or more codes. The codes and frequencies of the sub-themes are shown in Table 2.

Table 2. Positive views by the students about the environment

\begin{tabular}{|c|c|c|c|}
\hline Theme & Sub-theme & Code & Frequency (n) \\
\hline \multirow{8}{*}{ Positive } & \multirow{3}{*}{ Learning } & Enhance learning & 17 \\
\hline & & Understand concept & 15 \\
\hline & & $\begin{array}{l}\text { Enhance the interaction between instructor and } \\
\text { students }\end{array}$ & 12 \\
\hline & \multirow{5}{*}{ Engagement } & Raising concentration & 16 \\
\hline & & Raising motivation & 15 \\
\hline & & Entertaining environment & 13 \\
\hline & & Active participation & 13 \\
\hline & & Friendly Competition & 8 \\
\hline
\end{tabular}

As it can be seen in Table 2, the students expressed that this environment had positive effect on their learning, it enhanced their learning $(n=17)$, helped them positively to understand the concept $(n=5)$ and enhanced the interaction between the teacher and the students $(\mathrm{n}=12)$. Some sample statements of the students are as follows,

"We didn't talk a lot in class with other teachers. We just talked when we needed clarification. But with this application, we had more interaction with our teacher. He showed more interest in us and I liked his guidance. He didn't answer our questions directly, but guided us to find the answers ourselves". (S3) 
"It was difficult for me to understand concepts in lessons. I would try to memorize Physics at high school. But now I learned the concepts in detail. I can refer the concepts to daily life applications". (S14)

"We learned together with friends in class. We raised common ideas and answered questions. In case one didn't have any idea, the other had for compensation. Now we have the opportunity to talk more with our teacher and friends". (S20)

"We solved problems with team friends and sent the answers through Socrative and got fast feedback. This was a very effective procedure. We saw our mistakes by discussing and this helped our learning”. (S21)

The codes obtained under "Engagement" indicated that this environment increased their concentration $(n=16)$, motivation $(n=15)$ and provided an entertaining atmosphere $(n=13)$. In addition, the students emphasized that they had higher concentration $(n=13)$ and competed in a friendly manner $(n=8)$. Some sample statements of the students are provided below;

"I would get bored in Physics lessons. But this application has changed my views. I tried to understand the subject well during the first period because we would solve problems and compete. I can concentrate better on the meanings in Physics lessons". (S7)

"...actually I feel a bit shy when I try to raise my ideas. They may be misunderstood. I found out that now, with this application, when competing with others, time is important. Therefore, I participate in discussions and try to solve problems quickly. I even try to direct my friends. I wish this is applied in all subjects". (S13)

"It was fun to compete with teams. We would offer coffee to the winners. I had never thought Physics lesson would be so entertaining". (S18)

"I witnessed friends before who didn't like talking and sharing ideas. Now, I saw that they became very excited and struggles a lot for their teams to win. This method strengthened our relationship with our teacher and friends". (S6)

All these comments show that clicker supported team-based learning environment enhances student learning.

Students' negative opinions related to this environment are put in two different sub-themes; "personal characteristic oriented" and "technology oriented". Table 3 presents the codes of the sub-themes.

Table 3. Negative views of the students about the environment

\begin{tabular}{|c|l|l|c|}
\hline Theme & \multicolumn{1}{|c|}{ Sub-theme } & \multicolumn{1}{|c|}{ Code } & Frequency (n) \\
\hline \multirow{5}{*}{ Negative } & $\begin{array}{l}\text { Personal Character- } \\
\text { istics }\end{array}$ & Preference of traditional method & 2 \\
\cline { 2 - 4 } & $\begin{array}{l}\text { Technology } \\
\text { oriented }\end{array}$ & Negative rivalry & 1 \\
\cline { 2 - 4 } & Internet connection & 18 \\
\cline { 2 - 4 } & Using clicker in lectures waste too much time & 2 \\
\cline { 2 - 4 } & Lack of mobile phones or computer tablets & 2 \\
\hline
\end{tabular}

As it can be seen in Table 3, some students stated negative views about the environment and this was because of their personal characteristics. These students explained that they preferred traditional methods $(n=2)$ and added that competition in 
such an environment made them feel uncomfortable $(n=1)$. Some views are as follows;

"...... I would prefer my teacher gave the lesson and solved the questions on the board. We could ask for clarification of any points we did not understand". (S17)

"We are used to traditional methods. I don't like having lessons this way. I can learn better by listening to the teacher and taking notes". (S4)

"Competing in teams gives me a lot of stress. I don't like rivalry". (S9)

According to the codes under the theme of "technology oriented negativeness", it is seen that majority of the students explained that they had problems with internet connection $(\mathrm{n}=18)$. Some students expressed that excessive use of internet in the classroom was a waste of too much time $(\mathrm{n}=2)$. Only one student expressed dissatisfaction with the education in such an environment because they didn't have their phones or computer tablets.

"We frequently had internet connection problems while trying to have access to Socrative Space Race. This inconvenience affected the number of problems we were trying to solve. It was boring". (S15)

"For me, the most important problem was the internet connection. There was no internet connection for a few times while I was trying to send the problem answer through Socrative application. My friends who tried to send on their telephones did not face many connection problems. This, obviously demotivated us". (S11)

"I don't have a telephone or a tablet for this application. It didn't create a problem while working as a team, but it caused me stress. If we try it individually, I won't be able to do it". (S5)

The qualitative data obtained from the interviews reveal that majority of the students had positive views about the environment. It is believed that students with positive attitude towards the environment have an influence on their learning and engagement.

\subsection{The students' recommendations towards enhancing the clicker supported team-based learning environment}

In order to determine student recommendations about the environment, they were asked "You had Physics lesson in clicker supported team-based learning environment. What are your recommendations towards enhancing the environment to be used in the future? Explain". The data obtained were provided with two different themes, "application process" and "technology". Data were obtained from one student who expressed recommendations about one or more codes. The codes and frequencies related to these sub-themes are shown in Table 4.

As in Table 4, the students suggested that more than one class hour should be allocated for problem solving activities through Space Race $(n=13)$ under the theme of "Application process" and the groups should be composed of less than five people $(\mathrm{n}=10)$. Furthermore, some students suggested that other lessons should be carried out in this environment $(\mathrm{n}=7)$. Below are some sample statements of the students;

"It would be better to allocate more time to problem solving activities. For example, in the last twenty minutes we could solve problems through Space Race". (S1) 
"As a group of five, we wasted a lot of time for discussion. The number of students in each team should be smaller, three, for example”. (S8)

The students mostly suggested that internet connection problems in classrooms should be solved $(n=18)$ and lessons should be held in classrooms with proper internet connections and computers $(n=13)$.

"We had internet problems in connecting to Socrative. Such problems in classrooms should be solved. Such problems affect the flow of the lesson and cause loss of time". (S7)

"I suggest that such applications should be in classrooms with computers and internet”. (S12)

Table 4. Students' suggestions about the environment

\begin{tabular}{|l|l|c|}
\hline \multicolumn{1}{|c|}{ Theme } & \multicolumn{1}{|c|}{ Code } & Frequency (n) \\
\hline \multirow{4}{*}{ Application Process } & More time should be allocated to Space Race problem solving & 13 \\
\cline { 2 - 3 } & Teams should be smaller & 10 \\
\cline { 2 - 3 } & It should be applied in other subjects & 7 \\
\hline \multirow{3}{*}{ Technology } & Internet connection problems in classrooms should be solved & 18 \\
\cline { 2 - 3 } & $\begin{array}{l}\text { Lessons should be held in classrooms with computers or } \\
\text { internet }\end{array}$ & 13 \\
\hline
\end{tabular}

\section{$4 \quad$ Discussion and Conclusion}

Clicker supported team-based learning environment was developed in this study. Physics-I course was carried out in this environment for five weeks and student perceptions related to this environment were examined. The interviews with the students indicated that this environment enhanced learning. Receiving instant feedback after sending problem solving results on clickers could be effective in discussing any wrong answers reach the correct answer. It was also found out that this application increased student concentration and motivation, resulted in active participation and created an entertaining environment. In parallel with the findings in this study, [23] stated that using clicker in classrooms provided instant feedback for better learning and motivated students with low self-confidence and shyness. In addition, this environment developed students' feeling of work and working together. This finding of the present study is similar with [24] which stated that clicker activities in groups contributed significantly to learning, developed relationships and formed team-spirit as well as positive competition. Similarly, [25] stated that group-based interactive response system resulted in more student participation, raised motivation and created positive approaches. It is assumed that students' satisfaction with the clicker supported team-based learning environment was related with sound integration of team-based learning strategy into clicker technology.

One other important result of this study is that students preferred smaller teams. A study by [26] examined the positive effect of number of students in teams when using clicker-based strategies. This result supports the finding in this research. 
The results of this study showed the importance of the use of clicker technology with small groups and its integration into education in parallel to pedagogic approaches. Furthermore, this study revealed that clicker technology could be applied in harmony with team-based learning strategy.

\section{$5 \quad$ Limitations and Future Research}

As in other empirical studies, this research had limitations as well. Firstly, the participants were from a university in North Cyprus. Similar studies could be carried out in more than one university in the future. The second limitation was that participants were all male students. The effect of gender on the environment could be investigated among both male and female students in the future. The qualitative data were obtained through semi-structured interviews with the students. On the other hand, observation and document analysis might be also used as data collection tool. Another limitation in the present study was the five-week length. Future studies could be carried out for a longer period of time.

\section{References}

[1] Campbell, J. A. (2000). Using internet technology to support flexible learning in business education. Information Technology and Management, 1(4), 329-350.

[2] Hockly, N. (2014). Digital technologies in low-resource ELT contexts. ELT Journal, 68(1), 79-84. https://doi.org/10.1093/elt/cct063

[3] Zheng, W., Shi, J., Qiao, J., Xu, T., Feng, L., \& Fu, P. (2018). Virtual Laboratory Application Development for Mobile Terminal. International Journal of Online Engineering (iJOE), 14 (02), 76-89. https://doi.org/10.3991/ijoe.v14i02.7779

[4] Jonassen, D. H. (2007). Learning to solve complex scientific problems. New York: Lawrence Erlbaum Associates

[5] Çelik, S. (2015). Investigating the effect of student response system supported think-pairshare pedagogy on preparatory school EFL students' vocabulary achievement. Master Thesis Middle East Technical University, Ankara. Retrieved from http://etd.lib.metu. edu.tr/upload/12619511/index.pdf

[6] Moeller, B. \& Reitzes, T. (2011). Education development center, inc. (EDC). Integrating technology with student-centered learning. Quincy, MA: Nellie Mae Education Foundation.

[7] DeBourgh, G. A. (2008). Use of classroom "clickers" to promote acquisition of advanced reasoning skills. Nurse Education in Practice, 8(2), 76-87. https://doi.org/10.1016/ j.nepr.2007.02.002

[8] Wu, Y. C. J., Wu, T., \& Li, Y. (2017). Impact of using classroom response systems on students' entrepreneurship learning experience. Computers in Human Behavior, 1-12. http://dx.doi.org/10.1016/j.chb.2017.08.01

[9] Bartsch, R. A., \& Murphy, W. (2011). Examining the effects of an electronic classroom response system on student engagement and performance. Journal of Educational Computing Research, 44(1), 25-33.

[10] Bruff, D. (2009). Teaching with classroom response systems: creating active learning environments. (1st ed.) San Francisco: Jossey-Bass 
[11] Mareno, N., Bremner, M., \& Emerson, C. (2010). The use of audience response systems in nursing education: best practice guidelines. International Journal of Nursing Education Scholarship, 7(1). https://doi.org/10.2202/1548 923X.2049

[12] Blasco-Arcas, L., Buil, I., Hernandez-Ortega, B., \& Sese, F. J. (2013). Using clickers in class. The role of interactivity, active collaborative learning and engagement in learning performance. Computers \& Education, 62, 102-110. doi: https://doi.org/10.1016/j.comp edu.2012.10.019

[13] Addison, S., Wright, A., \& Milner, R. (2009). Using Clickers to Improve Student Engagement and Performance in an Introductory Biochemistry Class. Biochemistry and Molecular Biology Education. 37(2), 84-91. doi: https://doi.org/10.1002/Bmb.20264

[14] Oigara, J., \& Keengwe, J. (2018). Students perceptions of clickers as an instructional tool to promote active learning. Education and Information Technologies, $18(1), 15-28$.

[15] Shieh, R. S., Chang, W., \& Liu, E. Z. F. (2011). Technology enabled active learning (TEAL) in introductory physics: Impact on genders and achievement levels. Australasian Journal of Educational Technology, 27(7), 1082-1099.

[16] Trew, J. L., \& Nelsen, J. L. (2012). Getting the most out of audience response systems: predicting student reactions. Learning, Media and Technology, 37(4), 379-394. https://doi.org/10.1080/17439884.2011.621957

[17] Gachago, D., Morris, A., \& Simon, E. (2011). Engagement levels in a graphic design clicker class: Students' perceptions around attention, participation and peer learning. Journal of Information Technology Education: Research, 10, 253-269.

[18] Fuad, M.M., Deb, D., \& Etim, J. (2018). Mobile response system: a novel aproach to interactive and hands-on activity in the classroom. Educational Technology Research and Development, 66(2), 493-514. https://doi.org/10.1007/s11423-018-9570-5

[19] Tlhoaele, M., Suhre, C., \& Hofman, A. (2016). Using technology-enhanced, cooperative, group-project learning for student comprehension and academic performance. European Journal of Engineering Education,41(3), 263-278. https://doi.org/10.1080/030437 97.2015.1056102

[20] Hoekstra, A. (2008). Vibrant student voices: Exploring effects of the use of clickers in large college courses. Learning, Media and Technology, 33(4), 329-341. https://doi.org/10.1080/17439880802497081

[21] Miles, M.B. \& Huberman, A.M. (1994). Qualitative Data Analysis. London: Sage Publication.

[22] Şimşek, H., \& Yıldırım, A. (2011). Qualitative research methods in social sciences. Ankara: Seçkin Publications

[23] Hedgcock, W. H., \& Rouwenhorst, R. M. (2014). Clicking their way to success: using student response systems as a tool for feedback. Journal For Advancement of Marketing Education, 22(2), 16-25.

[24] McDonougha, K., \& Footeb, J. A. (2015). The impact of individual and shared clicker use on students' collaborative learning. Computers \& Education, 86, 236-249.

[25] Wang, Y. H. (2018). Interactive response system (IRS) for college students: individual versus cooperative learning. Interactive Learning Environments, 1-15 https://doi.org/10.1080/10494820.2017.1421563

[26] Kaiser, C. M., \& Wisniewski, M. A. (2012). Enhancing Student Learning and Engagement Using Student Response Systems. Social Studies Research \& Practice, 7(2), 137-149 
Paper-Clicker Supported Team-Based Learning Environment: A Qualitative Study

\section{Author}

Gülsüm Aşıksoy, Department of Computer Education and Instructional Technology, Ataturk Faculty of Education, Near East University, Near East Boulevard, ZIP:99138 Nicosia, Cyprus Mersin 10 Turkey. gulsum.asiksoy@neu.edu.tr

Article submitted 14 April 2018. Resubmitted 04 June and 18 July 2018. Final acceptance 26 July 2018. Final version published as submitted by the author. 